\title{
The New Design of the Close Fit Shielding Ring for SP-100
}

\section{T. Chiao}

Date Published

August 1991

To Be Presented at

New Horizons in Radiation

Protection Shielding

Pasco, Washington

April 26. May 1, 1992

Prepared for the U.S. Department of Energy Assistant Secretary for Nuclear Energy

\section{(2.) Westinghouse Hanford Company Richland, Washington 99352}

Hanford Operations and Engineering Contractor for the U.S. Department of Energy under Contract DE-AC 06-87RL10930

Copyright Licenae By nccoptance of this article, the publieher and/or recipiont acknowlodges the U.S. Government a right to colain a nonexclus ve, roy ahy. lioe ticense in and to any copyright covering this paper.

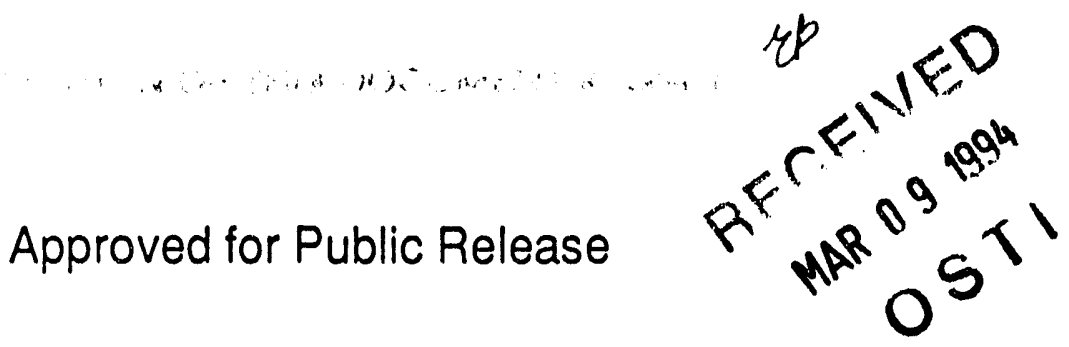




\section{LEGAL DISCLAIMER}

This report was prepared as an account of work sponsored by an agency of the United States Government. Neither the

Uniled Statos Government nor any agency therool, nor any of their employees, nor any of their contractors, subcontractors or their employoes, makes any warranty, expross or impliod, or assumes any logal liability or responsibility for the accuracy, complotonoss, or any third party's uso or the results of such use of any information, apparatus, product, or process disclosed, or represents that its use would not infringe privatoly ownod rights. Reforonco herein to any spocific commercial product, process, or service by trado name, trademark, manufacturer, or otherwise, does nol necessarily constitute or imply its ondorsement, recommendation, or favoring by the United States Government or any agency thereof or its contractors or subcontractors. The views and opinions of authors expressed herein do not necessarily stato or reflect those of the United States Government or any agency thereol. 
WHC- $=A-1332-5$

THE NEW DESIGN OF THE CLOSE FIT SHIELDING RING FOR SP-100

Tang Chiao

K'estinghouse Hanford Company

Richland, Wa. 99352 


\subsection{SUMMARY}

The SP-100 GES project has decided to remove the Near Reactor Shield (Reference 1) because of safety concerns about a large amount of water surrounding the reactor. However, other considerations become important when the Near Reactor Shield (NRS) is removed. For example, with the NRS removal the dose rate in the pump gallery shown in Figure 1 may be too high to be acceptable for normal operation of the vacuum pumps. Therefore, the thicknesses of the Close Fit Shielding Ring/Support Ledge, which separates the pump gallery and the Lower Reactor Cell, may have to increase substantially if the NRS is removed. The required increase in the thickness may become a limiting factor for these designs.

Substantial effort has been spent in the redesign of the close Fit Shielding Ring and the Support Ledge. Two different designs were considered. The first design, called Concrete Monolith design, would consist of a prefabricated monolithic ring formed to the shape of the vacuum vessel. A twoinch gap is allowed for all seismic, fabrication, thermal and installation needs. The second design, used as the Reference Design, would modify the Close fit Shielding Ring to become a part of the vacuum vessel as shown in Figure 1. A 1.5-inch gap would exist between the Close Fit Shielding Ring and the Support Ledge. The axial thicknesses of the Close Fit Shielding Ring and the Support Ledge would be increased to 45 inches in both designs. The material for the Concrete Monolith design would be high density concrete, but three different materials were under consideration for the Reference Design: 1). Zirconium Hydride $\left.\left(\mathrm{ZrH}_{2}\right), 2\right)$. Boron Carbide $\left(B_{4} C\right)$ and 3$)$, a combination of water $(70$ vol\%) and steel (30 vol\%). 
We calculated neutron and photon fluxes in the pump gallery and inside the reactor vessel during full power reactor operation for the two different designs. Also, the equivalent dose within the pump gallery after two years full power operations was derived.

The MCNP code (Reference 2) was used to make the dose rate calculations. The results for the Concrete Monolith design show very large increases in the radiation environment above the lower facility shield compared to corresponding calculations in Reference 1 which had the Near Reactor Shield. Specifically, the neutron flux between the lower and upper facility shields increased by factors of from 30 to 50 with typical nominal calculated values of the neutron flux within the control rod drive area being $1 \times 10^{9}$ neutrons $/ \mathrm{cm}^{2}$-second. The calculations indicate that the radiation fields at the safety rod drives inside the racuum vessel, rather than the pump gallery, are the limiting factors for this design.

The calculated neutron and photon doses within the pump gallery after two years of full power operation, based on the Reference Design, are listed in Table 1 for three different materials for the Close Fit Shielding Ring and the Support Ledge. The contribution from streaming within the gap between the Close Fit Shielding Ring and the Support Ledge is approximately 10 percent of these total dcses. The criterion set for the pump gallery is $1 \times 10^{9}$ rad after two years of full power operation. The current calculations show that the criterion in the pump gallery will be met by the Reference Design.

In summary, the calculations indicate that the Reference Design will meet the radiation criterion set for the pump gallery for all three materials. The gap between the Close Fit Shielding Ring and the Support Ledge contributes only $10 \%$ to the radiation in the pump gallery. However, the selection of 
material for the Close Fit Shielding Ring still depends on other factors such as heat distribution, cost, etc. The Concrete Monolith Design can not be accepted because the radiation field inside the reactor vessel becomes too high due to streaming though the gap.

Table 1 Accumulated Dose

in the Pump Galley in Units

of $10^{6} \mathrm{rad}$

Shielding Material

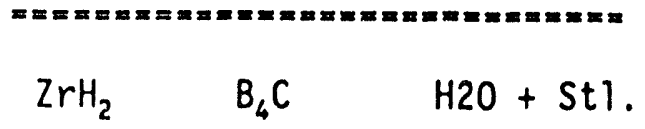

\begin{tabular}{|c|c|c|c|}
\hline Gamma-ray & 3.58 & 2.69 & 5.52 \\
\hline Neutron & 1.99 & 3.49 & 1.62 \\
\hline Total & 5.57 & 6.18 & 7.13 \\
\hline
\end{tabular}




\subsection{REFERENCE}

1. L. L. Carter and R. A. Schwarz, "Preliminary Shield Design for the SP-100 Ground Test," Presented at 6th Symposium on Space Nuclear Power Systems at Albuquerque, New Mexico on January 9-12, 1989.

2. J. F. Briesmeister, "MCNP-AGeneral Monte Carlo Code for Neutron and Photon Transport" Version 3A, LA-7396, Rev.2 1986. 

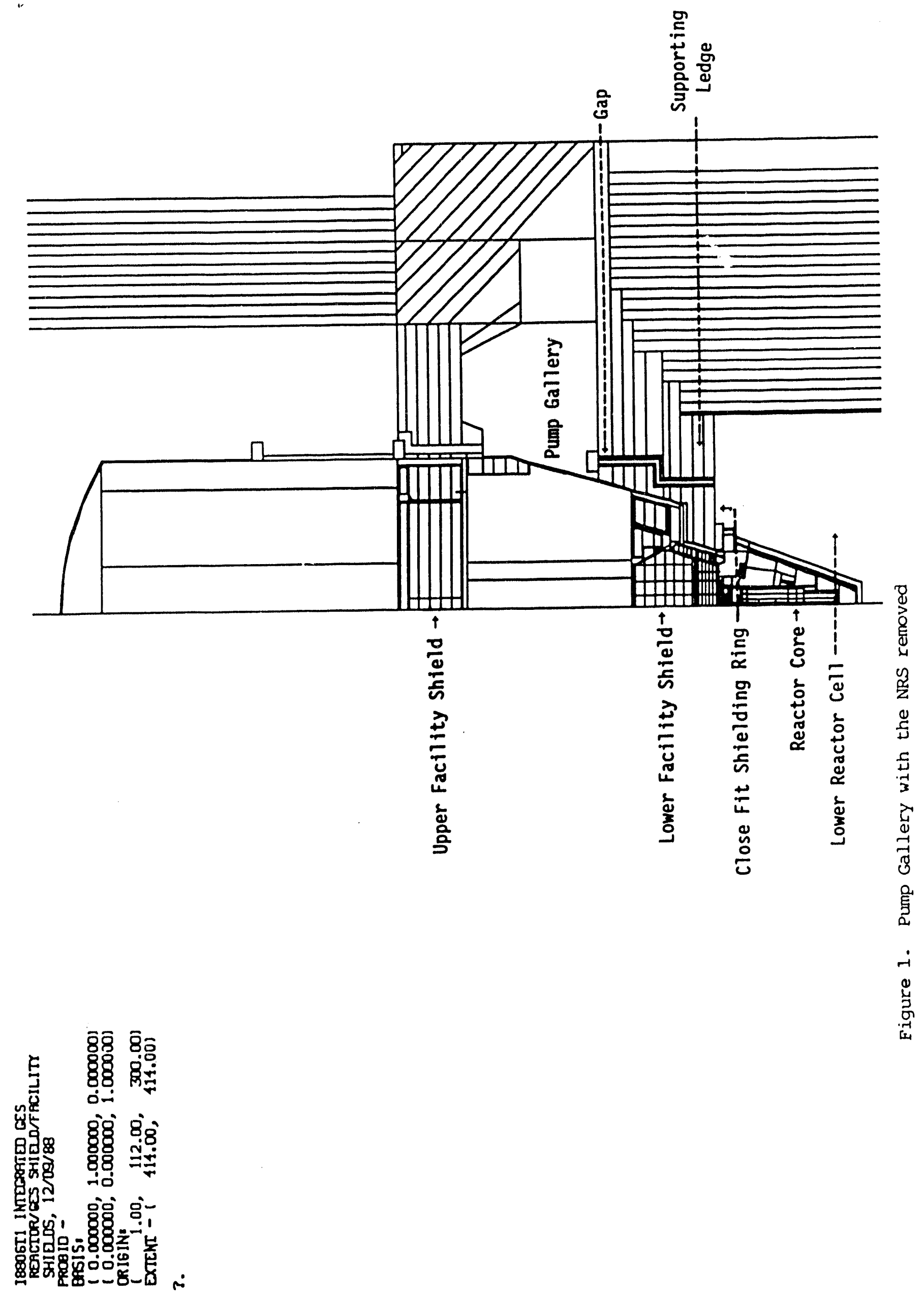

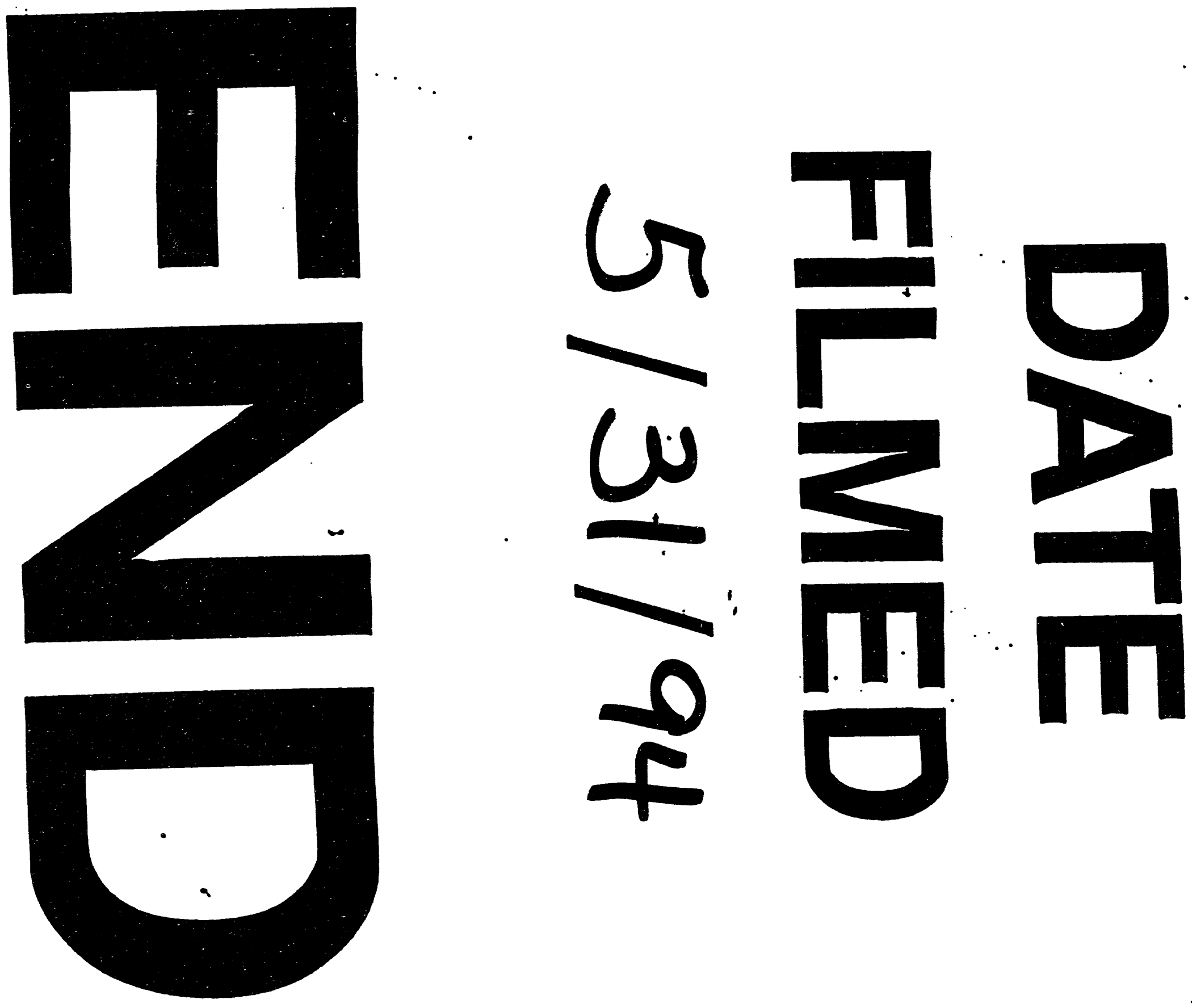
